\title{
ISM AL-TAFDHĪL DALAM ALQURAN JUZ 1 SAMPAI 10 (ANALISIS MORFOSINTAKSIS)
}

Taufiq Anshori SS.,M.pd

E-mail taufiq86anshori@gmail.com

\begin{abstract}
Abstrak
Ism al-tafdhīl merupakan sifat yang dibentuk dengan mengikuti wazan untuk muannats yang menunjukkan bahwa ada dua hal yang bersekutu akan tetapi salah satu melebihi yang lain dalam sifatnya. Dalam bahasa Indonesia disebut dengan istilah tingkat perbandingan sedangkan dalam bahasa Inggris disebut dengan istilah degree of comparation. Ism al-tafdhīl ini bersifat unik, artinya memiliki karakteristik yang berbeda dengan bahasa lainnya dalam proses dan aturan pembentukannya. Tujuan dari penelitian ini yaitu untuk mengetahui jenis ism al-tafdhīl, fungsi sintaksis sekaligus penanda gramatikal ism al-tafdhīl yang terdapat dalam Alquran juz 1 sampai 10. Penelitian ini merupakan penelitian kualitatif dengan desain penelitian library research. Pengumpulan data dilakukan dengan menggunakan teknik dokumentasi dengan kartu data dan lembar rekapitulasi sebagai instrumen penelitiannya, sedangkan proses pengambilan sampel dilakukan dengan menggunakan teknik purpose sampling. Adapun analisis datanya dilakukan dengan menggunakan teknik agih. Hasil penelitian ini menunjukkan bahwa ism al-tafdhīl dalam Alquran juz 1 sampai 10 secara keseluruhan berjumlah 194. Dari semua data tersebut, peneliti memilih 100 untuk dianalisis secara maksimal. Berdasarkan perubahan morfologisnya, terdapat 84 data perubahannya. Berdasarkan jenis pola strukturnya, terdapat 66 data tidak berupa murakkab idhāfi dan tidak dibubuhi. Berdasarkan jenis tingkat perbandingannya, terdapat 66 data komparatif dan 34 data superlatif. Berdasarkan fungsi sintaksisnya, terdapat terdapat 53 data menempati fungsi sintaksis khabar.
\end{abstract}

\footnotetext{
Abstract

Ism al-tafdhīl is an adjective formed by following wazan (pattern) فُلى لَّى for masculinity and for femininity that show two things have a same characteristic but one of them exceeds more than the others in that trait. In Indonesian is called tingkat perbandingan and in English is called degree of comparation. Ism al-tafdhil is unique, it has different characteristics from
} 
other languages in the proses and its formation. The purpose of this research is to know type of ism al-tafdhill on the Koran from juz 1 to 10. This research is a qualitative research with design library research. Data aggregation of this research use documentation method with data card and recapitulation thread in instrument while selection of sample data use purpose sampling method. Data analysis in this research use distributional method. The result of this research, shows that there are 194 ism al-tafdhill on the Koran from juz 1 to 10. From all of the datas, researcher chose 100 datas to be analalyzed. Based on morphological changes, there are 84 datas change from the basic word. Based on the syntactic structure, there are 66 datas are not relied on other word and affixed. Based on the type of comparation, there are 66 datas are comparative and 34 data are superlative. Based on the type of comparation, there are 66 datas are comparative and 34 data are superlative. Based on syntax functions, there are 53 datas as khabar.

\section{PENDAHULUAN}

Ism-al-tafdhil merupakan salah satu pembahasan dalam kaidah bahasa Arab yang dapat dikaji secara morfologis dan sintaksis. Menurut Aisyah (2007:275) ism al-tafdhil adalah sifat yang

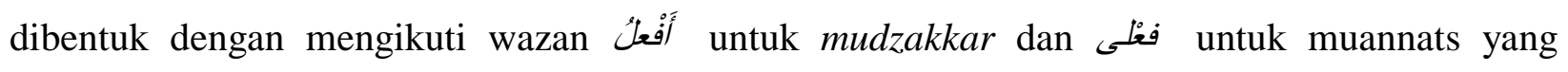
menunjukkan bahwa ada dua hal yang bersekutu dalam sifat akan tetapi yang satu melebihi yang lain dalam sifat tersebut.

Ism al-tafdhīl dalam bahasa Indonesia dikenal dengan istilah tingkat berbandingan, sedangkan dalam bahasa Inggris dikenal dengan istilah Eletives atau Degree of Comparation. Meskipun ketiga bahasa tersebut sama-sama mengenal kalimat perbandingan namun terdapat perbedaan dalam pola pembentukannya kata maupun kalimatnya. Pembentukan tingkat perbandingan dalam bahasa Indonesia dan bahasa Inggris aturannya lebih sederhana dibandingkan dengan pembentukan ism altafdhïl. Dalam bahasa Indonesia terdapat 3 jenis tingkat perbandingan, yaitu ekufatif, komparatif dan superlatif. Untuk menyatakan perbandingan ekuatif dalam bahasa Indonesia menggunakan formula se+ adjektiva atau sama+ kata sifat + -nya + dengan. Sedangkan untuk menyatakan tingkat komparatif menggunakan kata lebih...+daripada dan untuk menyatakan tingkat superlatif menggunakan formula paling/ter-+ kata sifat. Tidak berbeda dengan bahasa Indonesia, dalam bahasa Inggris juga terdapat 3 bentuk perbandingan, yaitu: (1) untuk menyatakan perbandingan positif bisa menggunkan as atau like, (2) untuk menyatakan 
bentuk komparafif menggunakan formula...more...than atau dengan menambahkan -er pada akhir kata sifat, more digunakan untuk kata sifat yang terdiri dari tiga suku kata atau lebih, dan (3) untuk menyatakan perbandingan superlatif, formula yang digunakan adalah dengan menambahkan - est pada adjektiva atau dengan adjektiva diawali adverbia most untuk kata sifat dari tiga suku kata atau lebih. Dalam bahasa Arab pembentukan ism altafdhīl dikaji dalam dua tinjauan (ilmu), yaitu morfologis (sharaf) dan sintaksis (nahwu). Ism altafdhīl altafdhīl dari

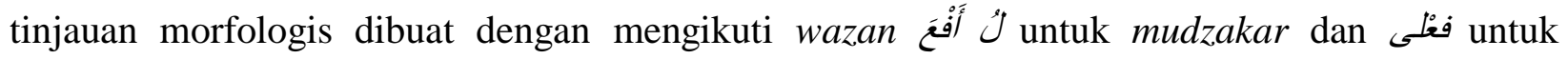
muannats, contoh: الثَّْْسُ أُكَبرُ مِن أُلََََر . Dalam bahasa Arab tidak semua kata dapat langsung dibuat menjadi ism al-tafdhīl dengan mengikuti wazan tersebut. Ada beberapa syarat yang harus dipenuhi, diantaranya: (1) berupa fi'il mujarrad tsulasiy, contoh: حسن dan (2) berupa fi'il mutsbat (kata kerja positif), (3) berupa fi'il mutasharrif, (4) berupa fi'il mabni ma'lūm, (5) berupa fi'il tāmm, (6) fi'il yang menerima untuk dilebihkan, dan (7) fi'il yang sifatnya tidak

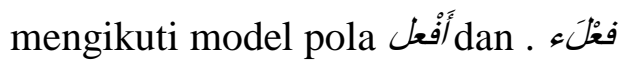

Apabila terdapat kata yang tidak memenuhi syarat tersebut dan ingin dibuat menjadi ism altafdhïl maka terdapat cara yang kedua, yaitu melalui perubahan dari bentuk dasar menjadi مصدر disertai dengan adanya penambahan ism al-tafdhīl dari lafal yang memenuhi syarat, seperti أكثر, أُجر, , أعظد , atau lafal lain yang serupa.

Dari tinjauan sintaksis ketentuan pembentukan ism al-tafdhīl didasarkan pada jenis pola struktur ism al-tafdhīl, terdapat 4 jenis pola struktur sintaksis, yaitu: (1) tidak berbentuk murakkab idhāfi dan tidak dibubuhi 2), ال) dibubuhi 3) berbentuk murakkab idhāfi dengan mudhāf ilaihnya nomina indefinite (4) berbentuk murakab idhāfi dengan mudhāf ilaihnya nomina definit. Ketentuan pembentukan ism al-tafdhīl pada setiap jenis pola struktur memiliki ketentuan yang berbeda-beda.

Apabila kita perhatikan uraian di atas, maka akan terlihat bahwa pembentukan ism altafdhïl lebih rumit dibandingkan dengan tingkat perbandingan dalam bahasa Indonesia dan bahasa Inggris. Ada banyak ketentuan, syarat, dan pola dalam pembentukan ism al-tafdhīl, sehingga ketika ingin membuat ism al-tafdhīl, maka kita harus terlebih dahulu memahami syarat pembentukannya, mengetahui jenis bentuk kata dasarnya, apakah berupa ism tsulatsi mujarrad atau ruba' $i$, dan lain sebagainya. Selain itu, dalam bahasa Arab juga belum dijelaskan secara rinci pembagian jenis tingkat perbandingan dari ism al-tafdhīl baik itu berupa komparatif maupun superlatif. Hal inilah yang menjadikan ism al-tafdhīl ini unik, berbeda dengan bahasa lainnya. Namun dengan adanya 
keunikan dan karakteristik tersebut seringkali menyulitkan pembelajar bahasa Arab sehingga pembahasan tentang bab ini sangat penting untuk diteliti dan dipelajari.

\section{LANDASAN TEORITIS}

\section{Morfologi}

Morfologi merupakan studi tentang pola suatu kata yang terdiri dari beberapa perubahan shighat/bentuk kata menurut sistem yang ada pada morfologi tersebut (Hidayat 2012:86). Dalam Kamus Besar Bahasa Indonesia (2008:930) disebutkan bahwa morfologi merupakan cabang linguistik tentang morfem dan kombinasi-kombinasinya atau bagian dari struktur bahasa yang mencakup kata dan bagian bagiannya.

Morfologi dalam bahasa Arab dikenal dengan istilah sharaf. Ilmu sharaf juga disebut dengan ilmu mufradāt atau ilmu tentang pembendaharaan kata, yaitu dalil-dalil yang memberikan kepada kita tentang keadaan kata-kata sebelum tersusun kedalam suatu kalimat, atau ilmu yang membahas bentuk dan kata-kata dalam bahasa Arab serta aspek-aspeknya sebelum tersusun dalam kalimat (Irawati 2013:101). Ilmu sharaf merupakan ilmu membahas tentang pembentukan kata (Ismail 2000:5). Oleh karena itu pembahasan ilmu sharaf hanya terletak pada ranah kata, bukan membahas tentang tataran yang lebih tinggi seperti frasa, klausa, kalimat dan wacana.

\section{Sintaksis}

Kata sintaksis berasal dari bahasa Yunani sun dan tattein yang berarti menempatkan. Kata sintaksis dalam bahasa Indonesia merupakan serapan dari bahasa Belanda syntaxis, yang dalam bahasa Inggris disebut syntax (Ramlan dalam Kuswardono 2013:1).

Sintaksis dalam bahasa Arab disebut ilmu nahwu yaitu ilmu yang mempelajari perubahan akhir kata maupun tetapnya kata tersebut.

\section{Ism al-Tafdhīl}

Ism al-tafdhīl adalah ism yang dibuat dengan mengikuti wazan افعل yang menunjukkan adanya dua hal yang bersekutu dalam sifat dan salah satunya melebihi yang lainnya dalam sifatnya (Alghany 2010:221). Menurut Busyro (2015:195) ism al-tafdhīl adalah ism yang berfungsi 
untuk menunjukkan bahwa ada dua benda yang berserikat dalam sifatnya tetapi salah satunya memiliki kelebihan.

Pendapat lain juga dikemukakan oleh Hanadi (2005:152), beliau mengungkapkan bahwasannya ism al-tafdhīl merupakan ism yang dibuat untuk menunjukkan dua hal yang berserikat dalam sifatnya tetapi salah satunya melebihi yang lain, baik lebih dalam keutamannya seperti احمل maupun lebih dalam kekurangannya seperti contoh: اسوا dan.

Ism al-tafdhīl hanya memiliki satu wazan yaitu فعلى (mudzakar) dannats). Namun adakalanya hamzah pada wazan فعل ini dibuang dalam tiga kata, yaitu: خبر, شر danya

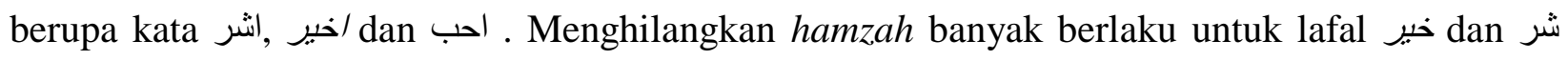
sedangkan untuk lafal حبب derhitung sedikit. Sebaliknya menetapkan hamzah pada lafal خَبَرِ dan شَ/Terhitung sedikit (Atiyah 2007:276).

Untuk membuat ism al-tafdhīl terdapat dua cara, yaitu pertama melalui perubahan dari bentuk dasar mengikuti model pola أَفْعَ dani terjadi apabila bentuk dasar kata ism al-tafdhīl memuhi syarat. Menurut Alghany (2010:223) syarat tersebut meliputi: (1) berupa fi 'il tsulāsī. (2) berupa fi'il mutsbat, tidak berupa fi 'il manfi, (3) berupa fi'il mutasharif, tidak berupa fi'il jamid, (4) berupa fi'il mabni ma'lūm, tidak berupa fi'il mabni majhūl, (5) berupa fi'il tamm, tidak berupa fi'il naqish, (6) fi'il yang menerima untuk dilebihkan, tidak boleh di bentuk dari fi'il sات,

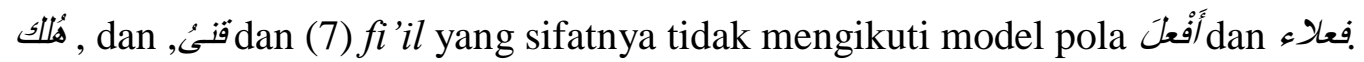

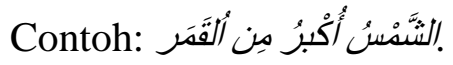

Cara pembentukan ism al-tafdhīl yang kedua yaitu melalui perubahan dari bentuk dasar menjadi أكثر disertai penambahan ism altafdhīl lain dari lafal yang memenuhi syarat seperti lafal جدر, أعظد , atau lafal lain yang serupa. Perubahan ini pada umumnya terjadi apabila bentuk dasar ism al-tafdhīl tidak memenuhi syarat yang telah disebutkan sebelumnya. Contoh:

الطلاب الملتز مون اكثر تفهما للغة العربية من غبرهم

Ism al-tafdhīl pada contoh diatas berupa اكثر تفهما. Pembentukan ism al-tafdhil dalam contoh ini yaitu dengan merubah bentuk dasar menjadi stem nomina original hal ini disebabkan karena lafal tidak memenuhi syarat pembentukan isim tadhil karena ia adalah fiil ghairu tsulāsī.

Dalam bahasa Arab pembentukan ism al-tafdhīl melalui perubahan ini tidak hanya berlaku ketika bentuk dasar ism al-tafdhïl tersebut tidak memenuhi syarat, namun cara ini juga 
boleh digunakan ketika bentuk dasar ism al-tafdhïl telah memenuhi syarat pembentukan secara langsung (Alghulayaini 2010:225).

1. Jenis Pola Struktur/Keadaan Ism al-Tafdhīl Keadaan/ jenis pola struktur ism al-tafdhīl ada 4, yaitu:

a. Tidak berbentuk murakkab idhäfi dan tidak tidak dibubuhi $\vee$. Dalam keadaan ini ism al-tafdhīlnya harus: mufrad, mudzakar dan nakiroh serta bertemu dengan harf jar نم. Contoh: سعيد خالد افضل من

b. Dibubuhi $\vee$. Dalam hal ini ism al-tafdhilnya harus disesuaikan dengan ism sebelumnya dalam hal mufrad, tatsniyah, jam', mudzakkar, dan muannatsnya serta الثقيقان هما الافضل : contoh, sن selahnya tidak boleh terdapat huruf,

c. Bentuk murokab idhafi dengan mudhaf ilaihnya nomina indefinite (nakiroh). Dalam hal ini harus mufrad, mudzakkar, nakiroh, dan setelahnya tidak boleh huruf من . Contoh : رجال المجاهدون افضل

d. Berbentuk murokab idhafi dengan mudhaf ilaihnya nomina defisit (ma'rifat). Dalam hal ini ism al-tafdhilnya tidak boleh bertemu dengan huruf من dan boleh mufrad, mudzakkar dan nakirah seperti ketika dimudhafkan dengan ism nakiroh dan boleh disesuaikan dengan ism sebelumnya sebagaimana ketika disertai ال

Contoh : النساء افضل فاطمة, هذان افضل القوم

\section{Ism al-Tafdhīl Komparatif dan Ism al-Tafdhïl Superlatif}

Jenis tingkat perbandingan ism al-tafdhīl dapat diketahui dengan cara melihat keadaan atau jenis pola struktur ism al-tafdhīl itu sendiri. Ketika jenis pola struktur sintaksis ism al-tafdhīl tidak berupa murokab idhāfi dan tidak pula dibubuhi ال, maka setelah ism al-tafdhīl pasti bertemu dengan huruf s baik secara lafdzi maupun muqaddarah, ini merupakan ism al-tafdhil komparatif karena adanya penambahan harf jar من setelah ism al-tafdhīl menunjukkan adanya dua hal yang diperbandingkan. Sebaliknya jika jenis pola struktur ism al-tafdhīl dibubuhi ال atau berbentuk murakkab idhafiy maka ism al-tafdhil tidak boleh bertemu dengan hurf jar su, sehinga ism al-tafdhil ini termasuk dalam jenis tingkat perbandingan superlative, karena tidak adanya من menunjukkan adanya komparasi mutlak atas banyak hal, tidak hanya atas dua hal. 


\section{METODE PENELITIAN}

Penelitian ini merupakan penelitian kualitatif dengan desain penelitian library research. Data dalam penelitian ini berupa ism altafdhīl yang terdapat dalam Alquran juz 1 sampai 10. Pengumpulan data dilakukan dengan menggunakan teknik dokumentasi, sedangkan proses pengambilan sampelnya dilakukan dengan menggunakan teknik purpose sampling. Instrumen yang digunakan berupa kartu data dan lembar rekapitulasi. Adapun analisis datanya dilakukan dengan menggunakan teknik agih.

\section{HASIL PENELITIAN DAN PEMBAHASAN}

Dalam Alquran juz 1 sampai 10, peneliti menemukan berbagai macam data berupa ism al-tafdhīl yang secara keseluruhan berjumlah 194 data. Dari semua data tersebut peneliti memilih 100 data untuk dianalisis secara maksimal. Peneliti mengidentifikasi dan mengelompokkan data tersebut berdasarkan jenis perubahan morfologis pembentukan ism al tafdhill, jenis pola struktur sintaksis, i'rab, serta jenis tingkat perbandingannya.

1. Ism al-tafdhīl berdasarkan jenis perubahan morfologis pembentukannya

Terdapat beberapa perubahan morfologis dalam pembentukan ism al-tafdhīl, diantaranya yang pertama perubahan secara langsung mengikuti model pola/wazan فعلى dan ف فعل , serta perubahan dari bentuk dasar menjadi مصدر disertai dengan adanya penambahan ism altafdhïl lain dari kata yang memenuhi syarat pembentukan ism al-tafdhīl secara langsung.

a. Perubahan dari bentuk dasar mengikuti model pola فحل

Berdasarkan analisis data yang dilakukan, peneliti menemukan 84 ism al-tafdhīl yang perubahan morfologisnya berupa perubahan dari bentuk dasar mengikuti model pola افعل . Salah satu kata yang pembentukannya melalui perubahan tersebut adalah حرص احرص .

Kata احرص merupakan kata yang memenuhi syarat, untuk itu bentuk perubahannya berupa perubahan dari bentuk dasar menjadi mengikuti model pola افعل dengan penambahan afiks yang berupa huruf hamzah (أ) pada awal kata.

Semisal dengan kata احرصyang perubahan morfologisnya berupa perubahan dari bentuk dasar mengikuti model pola افعل yang ditemukan peneliti dalam Alquran juz 1 sampai 10 اعضم , ارحم , اهدى , اسرع , اولون , احق , اضل , شر , اسفل , اصدق , اكثر , اعلون , اولى, adalah kata . احب dan اقو ام , اقسط, اقرب , اطهر , ازكى , اكابر , اكبر , الد , اعلم, احسن , اظلم , اند , ادنى , خير , اول 
b. Perubahan dari bentuk dasar mengikuti model pola فعلى

Berdasarkan analisis yang telah dilakukan, peneliti menemukan 9 data yang perubahan morfologisnya berupa perubahan bentuk dasar mengikuti model pola فعلى . Adapun contoh data yang mengalami perubahan tersebut adalah kata وثقى.

Kata berasal dari bentuk dasar merupakan kata yang memenuhi syaratpembentukan ism al-tafdhïl secara langsung,untuk itu bentuk perubahannya berupaperubahan langsung dari bentuk dasar menjadi mengikuti model pola. Semisal kata yang bentuk perubahan morfologisnya berupa perubahan dari bentuk dasar mengikuti model pola yang ditemukan peneliti dalam Alquran juz 1 sampai 10 adalah kata , dan

c. Perubahan dari bentuk dasar menjadi mashdar disertai penambahan ism altafdhīl dari lafal yang memenuhi syarat pembentukan secara langsung.

Berdasarkan analisis yang telah dilakukan, peneliti menemukan 7 data perubahan morfologisnya berupa perubahan dari bentuk dasar menjadi mashdar. Adapun contoh اشند قسوة dan اشد ئنبيتا فata yang mengalami perubahan tersebut adalah kata

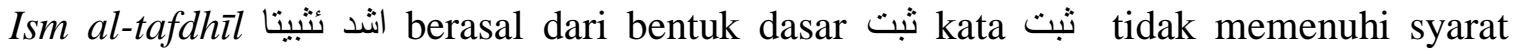
pembentukan ism al-tafdhïl secara langsung, karena merupakan fi'il tsulatsi mazīd biharf , oleh karena itu, pembentukan ism al-tafdhïlnya dengan mengubahnya kebentuk mashdar yaitu نثيت اشيتا

Ism al-tafdhīl شد قسوة berasal dari bentuk dasar قسا . Kata sebenarnya memenuhi syarat, namun dalam kalimat tersebut ism altafdhīlnya dibuat dengan mengubahnya kebentuk

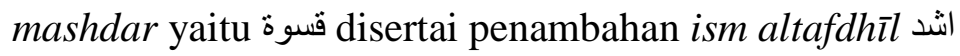

Semisal dengan kata اشند قسوة dan اشد تثيتاyang perubahan morfologisnya berupa perubahan dari bentuk dasar menjadi mashdar disertai dengan penambahan ism al-tafdhïl lain dari lafal yang memenuhi syarat yang ditemukan peneliti dalam Alquran juz 1 sampai10 اشد حر Ian اشدحبا, اشد ذكرا , اشد خشيه , اشد قوة adalah

2. Jenis Pola Struktur Ism al-Tafdhīl

Pola struktur ism al-tafdhīl ada 4, yaitu tidak berupa murakkab idhāfi dan tidak dibubuhi ال, dibubuhi ال ال berupa murakkab idhāfi dengan mudhāf ilaihnya nomina indefinite (nakiroh), dan berupa murakkab idhāfi dengan mudhāf alaihnya berupa nomina definit (ma'rifat).

a. Tidak berupa murakkab idhāfi dan tidak dibubuhi 
Berdasarkan analisis yang telah dilakukan, peneliti menemukan 66 data tidak berupa murakkab idhäfi dan tidak dibubuhi ال . Adapun contoh data yang jenis pola وماتخفي صدور هم اكبر adalah ال strukturnya tidak murakkab idhāfi dan tidak dibubuhi dan نأت بخير منها .

Kata dalam kalimat merupakan ism altafdhïl yang tidak berupa murakkab idhäfi dan tidak dibubuhi ال ال , untuk itu ism al-tafdhīlnya singular, maskulin dan indefinit, serta bertemu harf من baik lafdzi maupun muqaddarah. Dalam kalimat tersebut harf yang berfungsi menjarkan mufadhal alaih bersifat muqaddarah, takdirnya yaitu وماتخفي صدور هم اكبر مما يظهونه المانها

Kata خير dalam kalimat نأت بخير منها merupakan ism al-tafdhil yang tidak berupa murakkab idhafi dan tidak dibubuhi ال I, untuk itu ia singular, maskulin dan indefit, serta setelahnya bertemu harf من.

b. Dibubuhi ال

Berdasarkan analisis yang telah dilakukan, peneliti menemukan 15 data dibubuhi ال . Adapun contoh data yang jenis pola stukturnya dibubuhi adalah بالعروة الونقى dan

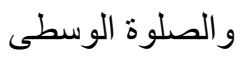

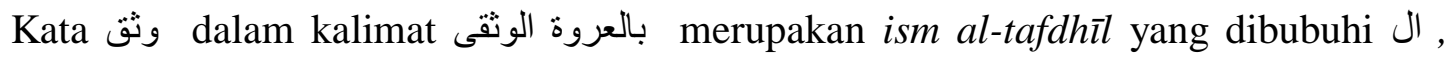
untuk itu bentuk ism al-tafdhïlnya disesuaikan dengan kata sebelumnya yang berupa kata العروة , yaitu berbentuk singular dan feminim serta setelahnya juga tidak terdapat harf jar من baik secara lafdzi maupun muqaddarah.

Kata الوسطى والصلوة merupakan merupakan ism al-tafdhīl yang وسطى dalam kalimat dibubuhi ال , untuk itu bentuk ism al-tafdhīlnya disesuaikan dengan kata sebelumnya yang berupa kata الوسطى , yaitu berbentuk singular dan feminim, serta setelahnya juga tidak terdapat harf jar ن baik secara lafdzi maupun muqaddarah.

c. Berupa murakkab idhāfi dengan mudhăfilaihnya nomina indefinite (nakiroh)

Berdasarkan analisis yang telah dilakukan, peneliti menemukan 2 data yang berupa murakkab idhäfi dengan mudhäf ilaihnya berupa nomina indefinite (nakiroh). Adapun data كنتم خير امة dan و لاتكوا اول كافربة tersebut adalah

Kata ول اول التكو اول كافربة merupakan ism al-tafdhïl yang berupa murakkab idhăfi dengan mudhāf ilaihnya berupa nomina indefinite (nakiroh) yaitu berupa kata untuk itu ism al-tafdhīlnya berbentuk singular, maskulin dan indefinit serta tidak bertemu harf من baik 
secara lafdzi maupun muqaddarah. Kata dalam kalimat merupakan ism al-tafdhīl yang berupa murakkab idhāfi dengan mudhāf ilaihnya berupa nomina indefinite (nakiroh) yaitu berupa kata خير, untuk itu ism al-tafdhīlnya berbentuk singular, maskulin dan indefinit serta tidak bertemu harf saik secara lafdzi maupun muqaddarah.

d. berupa murakkab idhāfi dengan mudhāf ilaihnya nomina indefinite (nakiroh)

Berdasarkan analisis yang telah dilakukan peneliti penemukan 17 data berupa murakkab idhāf $i$ dengan mudhāf ilaihnya nomina definit (ma'rifat). Adapun contoh data jenis pola struktur ini

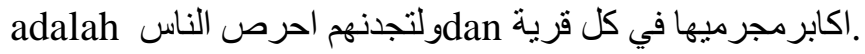

merupakan ism al-tafdhīl yang berupa murakkab idhāfi dengan mudhāf ilaihnya nomina definit (ma'rifat) ) yaitu kata اناس. Adapun ketentuan bentuk ism al-tafdhīlnya yaitu seperti ketentuan bentuk ism al-tafdhīl ketika jenis/pola strukturnya berupa murakkab idhāfi dengan nomina indefinite (nakiroh), hal ini dikarenakan meskipun kata sebelumnya berupa isim dhamir jam' ولتجدنهم, ism al-tafdhīlnya tetap berbentuk أحرصي الناس 'tidak berbentuk plural (jam احرص الناس singular, maskulin dan indefinite yaitu

Kata kata dalam kalima diidhafahkan dengan nomina definit yang berupa kata مجرميها . Ketita pola struktur ism altafdhīlnyaberupa murokab idhāfi dengan mudhāf ilaihnya nomina definit maka ism al-tafdhīlnya boleh singular mufrad seperti ketika berupa murakkab idhāfi, dengan mudhāf ilaihnya nomina indefinite atau boleh disesuaikan dengan isim sebelumnya seperti ketika dibubuhi ال Dalam ayat ini ism al-tafdhīlnya disesuaikan dengan ism sebelumnya untuk itu ia berbentuk plural (jam'), serta tidak bertemu dengan harf jar من baik secara lafdzi maupun muqaddarah.

\section{Ism al-tafdhīl berdasarkan Jenis Tingkat Perbandingannya}

Berdasarkan analisis yang telah dilakukan, peneliti menemukan 66 data berupa ism al-tafdhïl komparatif dan 34 data berupa ismal-tafdhīl superlatif.

Adapun salah satu data yang berupa komparatif adalah كنا أهدى منهم. Ism al-tafdhïl dalam kalimat tersebut berbentuk komparati karena ism al-tafdhīlnya yang berupa katass tidak berupa murakkab idhāfi serta tidak dibubuhi ال oleh karenanya terdapat huruf jar من yang terletak setelah ism al-tafdhïl. Adanya harf jar s yang menunjukkan adanya komparasi antara dua hal.

4. Salah satu data yang berbentuk superlati adalah و هو اسدع الحاسبين. Ism al-tafdhīl pada kalimat tersebut berbentuk superlatif karena ism al-tafdhīlnya yang berupa kata أسرع diidhafahkan dengan nomina definit sehingga setelahnya tidak terdapat huruf jar w saik itu secara lafdzi 
maupun muqaddarah. Tidak adanya harf jar setelah ism al-tafdhīl menunjukkan adanya komparasi mutlak atau banyak hal, tidak hanya atas dua hal.

5. Ism al-tafdhīl berdasarkan Fungsi Sintaksisnyaterdapat terdapat 53 data menempati fungsi sintaksis sebagai khabar, 12 data menempati fungsi sintaksis sebagai ma'thuf, data menempati menempati fungsi sintaksis sebagai na'at, 8 data menempati fungsi sintaksis sebagai khabar $k \bar{a} n a, 6$ data menempati fungsi sintaksis sebagi maf'ul bih, 6 data menempati fungsi sintaksis sebagai majrur, 3 data menempati fungsi sintaksis sebagai ism inna, 1 data menempati fungsi sinaksis sebagai khaba inna, 1 data menempati fungsi sintaksis sebagi fà' $i l, 1$ data menempati fungsi sintaksis sebagai mudhäf ilaih, dan 1 data sebagai badal. Ism altafdhīl.

\section{Ism al-tafdhīl Berdasarkan Penanda Gramatikalnya}

Berdasarkan ciri gramatikalnya, dalam penelitian ini terdapat 61 data ism al-tafdhīl beri'rāb rafa' (berkasus nominatif), 22 data ism altafdhīl beri'rāb nashab (berkasus akusatif), 16 data ism al-tafdhīl beri'rābjar (berkasus genetif), dan data ism al-tafdhīl mahal rafa' (menempati tempatnya $r a f a$ '). Dari 61 data ism al-tafdhīl yang beri'rāb rafa' (berkasus nominatif), peneliti menemukan 50 data desinennya berupa harakat dhummah, 9 data desinennya berupa dhummah muqaddarah 1 data desinennya berupa harf waw dan 1 data desinennya berupa harf alif. Adapun dari keseluruhan data ism al-tafdhīl yang beri'rāb nashab (berkasus akusatif), peneliti menemukan 18 data desinennya berupa harakat fathah dan 4 data desinennya berupa fathah muqaddara,sedangkan dari 16 data ism al-tafdhīl yang beri'rābjar (berkasus genetif), peneliti menemukan 7 data desinennya berupa harakat kasrah, 6 data desinennya berupa kasrah muqaddarah, 2 data desinennya berupa harakat fathah, dan 1 data desinennya berupa harf ya'.

\section{SIMPULAN}

Berdasarkan analisis data yang telah dijabarkan pada bab sebelumnya, dapat disimpulkan bahwa data yang dianalisis peneliti dalam Alquran juz 1 sampai 10 berjumlah 100 data berupa ism altafdhīl.

Berdasarkan jenis perubahan morfologis pembentukannya, terdapat 84 data pembentukannya melalui perubahan bentuk dasar mengikuti model pola فعلىdata mengikuti model pola فحلى 9 dan 7 data melalui perubahan dari bentuk dasar menjadi mashdar disertai penambahan ism al-tafdhīl lain dari lafal yang memenuhi syarat. Adapun prosentasenya adalah sebagai berikut: 


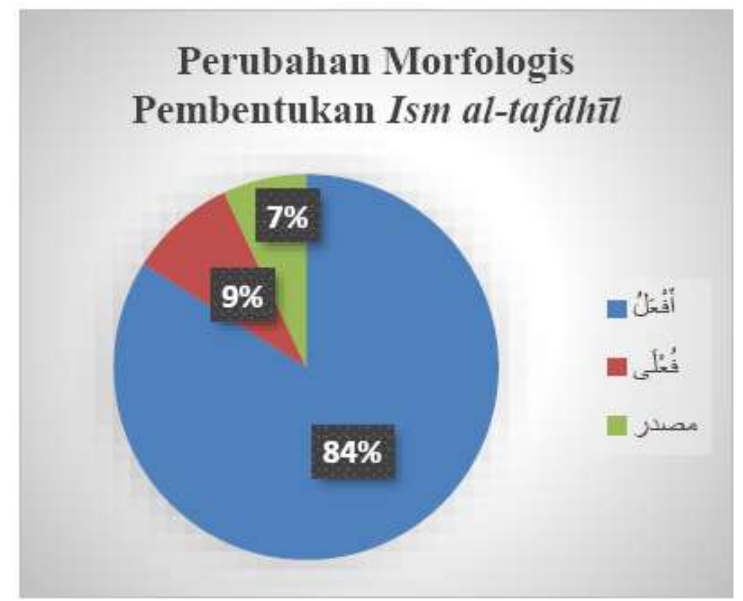

Berdasarkan jenis pola struktur ism al-tafdhil, terdapat 66 data tidak berupa murakkab idhāfi dan tidak dibubuhi 15, ال data dibubuhi ال, 2 data berupa murakkab idhāfi dengan mudhāf ilaihnya nomina indefinite (nakiroh), dan 17 data berupa murakkab idhāfi dengan mudhāfilaihnya nomina definit (ma'rifat). Adapun prosentasenya adalah sebagai berikut:

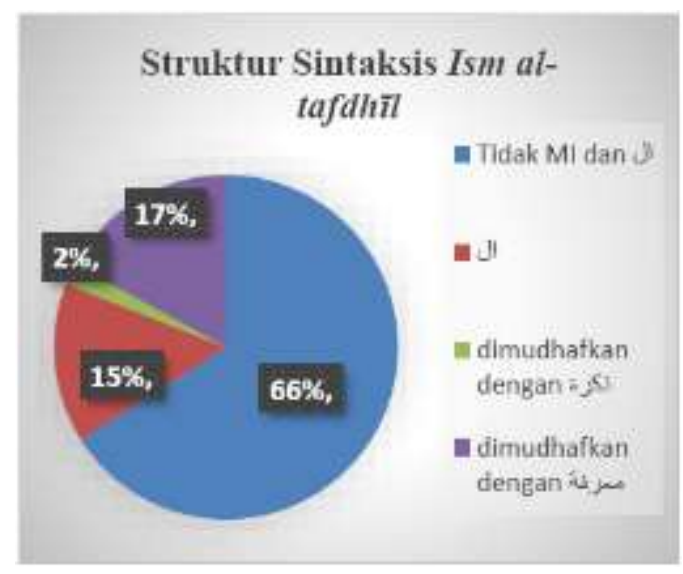

Berdasarkan jenis tingkat perbandingannya, terdapat 66 data berupa ism al-tafdhil komparatif dan 34 data berupa ism al-tafdhil superlatif. Adapun prosentasenya adalah sebagai berikut:

Jenis Tingkat Perbandingan Ism al-

Tafdhïl

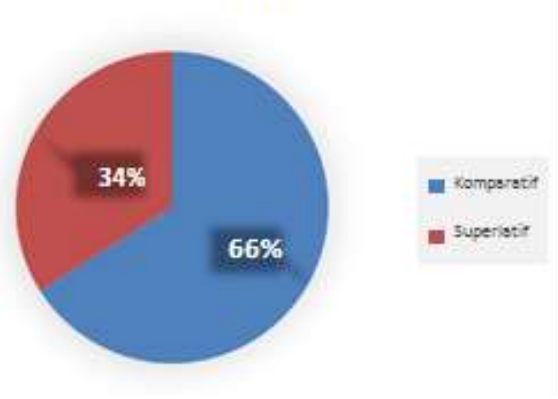


Berdasarkan fungsi sintaksisnya, terdapat terdapat 53 data menempati fungsi sintaksis sebagai khabar, 12 data menempati fungsi sintaksis sebagai ma'thuf, 9 data menempati menempati fungsi sintaksis sebagai na'at, 8 data menempati fungsi sintaksis sebagai khabar kāna, 6 data menempati fungsi sintaksis sebagi maful bih, 6 data menempati fungsi sintaksis sebagai majrur, 3 data menempati fungsi sintaksis sebagai ism inna, 1 data menempati fungsi sintaksis sebagai khabar inna, 1 data menempati fungsi

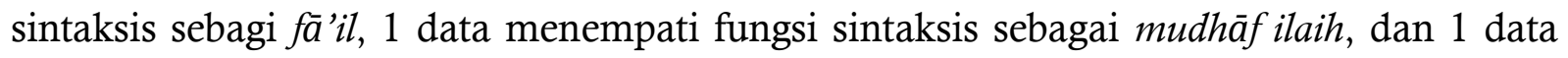
sebagai badal.

Berdasarkan ciri gramatikalnya, dalam penelitian ini terdapat 61 data ism al-tafdhil beri'rāb rafa' (berkasus nominatif), 22 data ism al-tafdhỉ beri'rāb nashab (berkasus akusatif), 16 data ism al-tafdhil beri'rābjar (berkasus genetif), dan 1 data ism al-tafdhil mahal rafa' (menempati tempatnya rafa'). Dari 61 data ism al-tafdhil yang beri'rāb rafa' (berkasus nominatif), peneliti menemukan 50 data desinennya berupa harakat dhummah, 9 data desinennya berupa dhummah muqaddarah 1 data desinennya berupa harf waw dan 1 data desinennya berupa harf alif. Adapun dari keseluruhan data ism al-tafdhil yang beri'rāb nashab (berkasus akusatif), peneliti menemukan 18 data desinennya berupa harakat fathah dan 4 data desinennya berupa fathah muqaddara, sedangkan dari 16 data ism al-tafdhil yang beri'rābjar (berkasus genetif), peneliti menemukan 7 data desinennya berupa harakat kasrah, 6 data desinennya berupa kasrah muqaddarah, 2 data desinennya berupa harakat fathah, dan 1 data desinennya berupa harf ya'. 


\section{DAFTAR PUSTAKA}

\section{Buku}

Alghani, Aiman Amin A. 2010.

Al-Sharfu Al-Kafi. Kairo: Dar Al-Taufiqiyah Lil-turats. Alghulayaini, Musthafa. 2006.

Jami'u al-Durus al-Arabiyah. Libonan: Dar al-Fikri Lithiba'ati wa al-Nasyri wa AlTauzi'. 2010.

Al-Nahw Al-Kafi. Kairo: Dar Al-Taufiqiyah Lil-turats Athiyah, Muhsin Ali. Al-Wadhih fi al-

Qawaidi al- Nahwiyah wa al-Abniyah al-Sharfiyah. Oman: Daru al-Manahij Linnasyri wa alTauzi'. Ibnu 'Aqil, Bahauddin Abdullah I. 2009.

Terjemahan Alfiyah Ibnu Malik Syarah Ibnu A’qil. Bandung: Sinar Baru Algensindo Busyro, Muhtarom. 2015.

Shorof Praktis Metode Krapyak. Yogyakarta: Putra Menara Chaer, Abdul. 2007.

Linguistik Umum. Jakarta: Rineka Cipta. Irawati, Retno Purnama. 2013.

Pengantar Memahami Linguistik.. Semarang:. Penerbit Cipta Prima Nusantara Semarang. Kamus Besar Bahasa Indonesia. 2008.

Jakarta: PT. Gramedia Pustaka Utama Kuswardono, Singgih. 2013.

Sintaksis dan Sejarah Awal Kemunculannya. Hand Out 2010 عُبد أُمبن أبين ,ألغنس

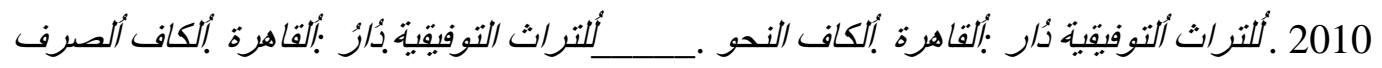

2006 بُصطفى يُيين الغلَ

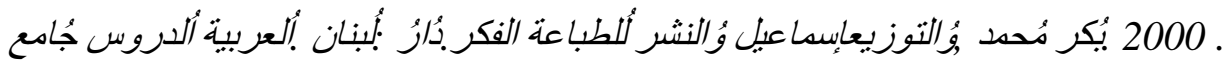

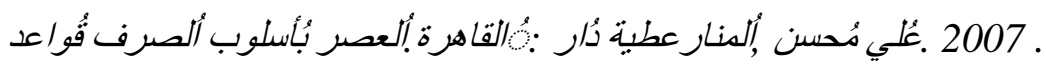

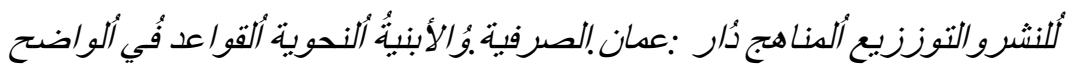

\section{Jurnal}

Hanadi, Muhammad Ibn Abdulkadir. 2005.

On The Anomalous Comparative Form (Af’ala).1:151-189.

Hidayat, Nandang Sarip. 2012.

ProblematikaPembelajaran Bahasa Arab. Jurnal Pemikiran Islam.1:82-87 